Higher Education 8 (1979) 553-572

(c) Elsevier Scientific Publishing Company, Amsterdam - Printed in the Netherlands

\title{
CAREER PATTERNS OF U.S. MALE ACADEMIC SOCIAL SCIENTISTS
}

\author{
ROBERT T. BLACKBURN \\ Center for the Study of Higher Education, University of Michigan, Ann Arbor, MI., U.S.A.
}

ROBERT J. HAVIGHURST

Committee on Human Development, University of Chicago, Chicago, IL., U.S.A.

\begin{abstract}
Seventy-four U.S. male academic social scientists provided career stage data. All were born between 1893 and 1903. The subjects were divided into four groups on the basis of their scholarly article productivity after age 59. Spilerman's conceptualization of work history guided the analysis. To a lesser extent, adult development theory (e.g., Hall and Nougaim, 1968) was also examined.

Critical career events were content analyzed and compared. Distinct career paths through and beyond retirement emerged. Among other things, the active publishers have had a less varied career in terms of the different academic roles possible in colleges and universities. Obtaining the Ph.D. followed by research in one setting well beyond retirement characterize these individuals. The moderately active and inactive publishers began their work history with high school teaching and administration, later had college posts as department heads or deanships, and reported sharper separation from academic work at age 65 .

The importance of early start and place of work support Spilerman's contention of the organization shaping the individual. Career events did not cluster at either chronological or career ages and hence fail to corroborate adult development theorists.
\end{abstract}

\section{Introduction and Conceptual Framework}

The study of career lines - entry portals, job trajectories, status, satisfaction, etc. - is coming into its own again in sociology (see, e.g., Spilerman, 1977). The data presented here make a special contribution to this literature for they come from a population extending longitudinally over 72 to 82 years. Many of these individuals were pioneers in the emerging social scientific disciplines, particularly in psychology and sociology. In addition, construction of the work histories of these U.S. male academic social scientists leads to the identification of variables that account for their careers and permits a comparison with current studies of professors. Finally, 
because of the mode of analysis developed here, some observations can be made with regard to the emerging theory of adult development (e.g., see Hall and Nougaim, 1968).

\section{POPULATION}

The 74 subjects are a subset of 160 respondents to whom two long questionnaires were sent in 1975. They came from a universe of 779 men who principally had had academic careers. (The population and sampling procedure are described in Havighurst et al. (1979).) The response rate is slightly over $50 \%$, but the exact number is impossible to ascertain because of difficulties in securing current addresses, the potential respondent's health, and an unknown (but not insignificant) mortality rate.

\section{METHODOLOGY}

The respondents were grouped on the basis of their scholarly productivity between ages 59-70. Those who had published at least one article in each of the four-three-year age intervals $(59-61,62-64,65-67,68-70)$ were called Very Actives (VA's); those who published in three of these intervals were called Actives (A's); those who published in any two of these intervals were called Moderately Active (MA's); and those who had not published at all or only in one of the four intervals were called Inactives (I's).

These 74 persons adequately responded to a lengthy item which had them identify by time (chronological age) the ten major events of their career. They gave brief descriptions (from a phrase to a sentence or two) of each event and later identified the two or three of these salient events which were most important in their careers.

The career events were then content analyzed. The 690 mentioned career events were reduced to eight major career stages and/or types of event, each having subcategories (see "Findings" below). Slightly less than two percent of the responses were either unclear or fell outside of the principal categories. The events checked as most important (see starred $\left(^{*}\right)$ events in tables below) were plotted on (1) age lines and on (2) career lines from (a) time since receipt of Ph.D. and on (b) time since first regular academic position.

\section{Findings}

The first column in Table $I$ is the number of subjects in each of the groups. Each of the following tables will always combine the VA's with the A's as well as treat them separately. The next column deals with the number 


\section{TABLE I}

The Sample

\begin{tabular}{|c|c|c|c|c|c|}
\hline Group & Number & $\begin{array}{l}\text { Total } \\
\text { number } \\
\text { of events } \\
\text { (e) men- } \\
\text { tioned }\end{array}$ & $\begin{array}{l}\text { Average } \\
\text { number } \\
\text { of e's per } \\
\text { respon- } \\
\text { dent }\end{array}$ & $\begin{array}{l}\text { Number } \\
\text { of most } \\
\text { impor- } \\
\text { tant e's } \\
\text { record- } \\
\text { ed (*s) }\end{array}$ & $\begin{array}{l}\text { Percent- } \\
\text { age of } * s \\
\text { per group }\end{array}$ \\
\hline Very Active (VA) & 10 & 89 & 9 & 24 & 27 \\
\hline Actives (A) & 9 & 90 & 10 & 22 & 24 \\
\hline$[\mathrm{VA}+\mathrm{A}]$ & [19] & [179] & [9] & [46] & [26] \\
\hline Moderately Active (MA) & 24 & 232 & 9 & 58 & 25 \\
\hline Inactives (I) & 31 & 279 & 9 & 75 & 27 \\
\hline Totals (average) & 74 & 690 & (9) & 179 & $(26)$ \\
\hline
\end{tabular}

of career events that were mentioned by the number of people in that category. Not all respondents listed ten events. They ranged from a low of 4 to a high of 13. The average number of events (abbreviated with a small "e") is almost identical per group, namely 9 . The next column in Table I indicates the number of starred $(*)$ events for each group, and the last column shows what percentage of the events by that group were actually starred. There is uniformity from group to group. Essentially one-fourth of the events that were listed were starred.

Table II is a summary of the event categories established after analyzing the 690 e's and the 179 *'s. As can be seen in Table II, the sequence has the attributes of a career line. For the central part of the career, after the first appointment, events going on within colleges and universities would coincide with job changes either within or without higher education. But job changes seem to be one kind of thing and events within colleges and universities were quite different, and were so noted. Also, honors received and personal matters could have occurred during job changes or as events within colleges and universities, and in fact, some did. However, most honors were noted much later in a person's career and so more accurately farther down the career line.

The first column in Table II simply represents the percentage of the 74 people who mentioned an event classified in that major career stage. This varies from the high of 86 down to a low of 19. (In fact, that 19 is a subclass and so should not be treated as insignificant within the larger category which really has a higher percentage of the people responding.) The second column expresses the percentage of e's of the total e's that fell into each of 


\section{TABLE II}

e's and *'s by Career Stage and/or Event, in Percentages

\begin{tabular}{|c|c|c|c|}
\hline Career stage events & $\begin{array}{l}\text { Percentage } \\
\text { respondents } \\
\text { who men- } \\
\text { tion each e }\end{array}$ & $\begin{array}{l}\text { Percentage } \\
\text { e's of } \\
\text { total e's }\end{array}$ & $\begin{array}{l}\text { Percentage } \\
\text { *'s of } \\
\text { total *'s }\end{array}$ \\
\hline Pre PhD activities & 58 & 13 & 7 \\
\hline PhD and graduate school & 86 & 13 & 18 \\
\hline First $\mathrm{CU}^{\mathrm{a}}$ appointment & 85 & 11 & 14 \\
\hline Job changes & 68 & 16 & 20 \\
\hline within higher education & (36) & (5) & (5) \\
\hline outside higher education & (53) & (11) & (15) \\
\hline Events within CUs ${ }^{\mathrm{a}}$ & 82 & 23 & 29 \\
\hline publications & (46) & (8) & (7) \\
\hline overseas experiences & (19) & (2) & (4) \\
\hline changes in status or role & (73) & (13) & $(18)$ \\
\hline Honors received & 42 & 9 & 7 \\
\hline Personal matters & 34 & 5 & 2 \\
\hline Retirement & 72 & 9 & 3 \\
\hline Miscellaneous/unclassifiable & 14 & 2 & 0 \\
\hline Totals & & $101^{b}$ & 100 \\
\hline
\end{tabular}

${ }^{\text {a }} \mathrm{CU}=$ College and/or University; $\mathrm{CU}=$ Colleges and/or Universities.

$\mathrm{b}$ In this and other Tables rounding errors may produce Totals which differ slightly from $100 \%$.

the career stage categories. These vary, but they average about 11 . That is, the categories are not so large as to include every thing and not so small as to be insignificant. The last column shows the fraction of most important e's (the *'s) expressed in percent. What can be seen is that for some career events a higher percentage of e's than *'s took place, and vice versa. For example, while pre-Ph.D. activities constituted $13 \%$ of all of the events mentioned, they make up only $7 \%$ of the most significant (*ed) ones [1].

In Table III the first five columns are for the four sub-categories with the third column being the sum of the first two, the VA's plus the A's. The last, or six th column, in each of the sub-tables as well as the total table, is the sum for all of the 74 cases. The first line of a section of a table is always the number of persons within that group mentioning the event. For example, obtaining the B.A. was mentioned by one of the ten people in VA and that is indicated by a 1 followed by (10) for 10\%. The second row in each table differs from the top one in that it enumerates the number of times a particular event was mentioned. In the first sub-table on the B.A., in the upper lefthand corner of Table III, it transpires that the number of times an event 
was mentioned was exactly the same as the number of persons mentioning the event. But that is not always the case as can be seen in the sub-table immediately below, "Obtaining the M.A.". There one of the I's mentioned getting a master's degree on two different occasions. (The person obtained

\section{TABLE III}

Pre-Ph.D. Activities

\begin{tabular}{|c|c|c|c|c|c|c|c|}
\hline & \multicolumn{7}{|c|}{$\begin{array}{l}\text { EDUCATION } \\
\text { Obtaining the B.A. }\end{array}$} \\
\hline & $\begin{array}{l}\text { VA } \\
\text { N }(\%)\end{array}$ & $\begin{array}{l}\mathrm{A} \\
\mathrm{N}(\%)\end{array}$ & \multicolumn{2}{|c|}{$\begin{array}{l}\mathrm{VA}+\mathrm{A} \\
\mathrm{N}(\%)\end{array}$} & $\begin{array}{l}\text { MA } \\
\text { N }(\%)\end{array}$ & $\begin{array}{l}\mathrm{I} \\
\mathrm{N}(\%)\end{array}$ & $\begin{array}{l}\text { Total } \\
\text { N }(\%)\end{array}$ \\
\hline $\begin{array}{l}\text { Number of persons } \\
\text { mentioning } \mathrm{e}\end{array}$ & $1(10)$ & $3(33$ & 3) & $4(21)$ & $9(38)$ & $17(55)$ & $30(41)$ \\
\hline Number of mentions & $1(33)^{\mathrm{a}}$ & $3(38$ & & $4(36)$ & $9(28)$ & $17(35)$ & $30(33)$ \\
\hline Number of *'s & $\begin{array}{l}0 \quad(0) \\
\text { Obtainir }\end{array}$ & $\begin{array}{c}0 \\
\text { ing the } \mathrm{M}\end{array}$ & $\begin{array}{l}0) \\
\text { 0) } 0\end{array}$ & $0 \quad(0)$ & $2(67)^{b}$ & $1(17)$ & $3(23)$ \\
\hline $\begin{array}{l}\text { Number of persons } \\
\text { mentioning e }\end{array}$ & $0 \quad(0)$ & $2(22$ & & $2(11)$ & $10(42)$ & $8(26)$ & $20(27)$ \\
\hline Number of mentions & $(0)$ & $2(25)-x)$ & & $2(18)$ & $10(31)$ & $9^{c}(19)$ & $21(23)$ \\
\hline Number of *'s & $(0)$ & $0 \quad(C$ & 0) & $0 \quad(0)$ & $0 \quad(0)$ & $0 \quad(0)$ & $0(0)$ \\
\hline Education Totals & & $\begin{array}{l}\text { VA } \\
N(\%)\end{array}$ & $\begin{array}{l}\mathrm{A} \\
\mathrm{N}(\%)\end{array}$ & $\begin{array}{l}\mathrm{VA}+\mathrm{A} \\
\mathrm{N}(\%)\end{array}$ & $\begin{array}{l}\text { MA } \\
\text { N (\%) }\end{array}$ & $\begin{array}{l}\mathrm{I} \\
\mathrm{N}(\%)\end{array}$ & $\begin{array}{l}\text { Total } \\
\mathrm{N}(\%)\end{array}$ \\
\hline $\begin{array}{l}\text { Number of persons } \\
\text { mentioning e }\end{array}$ & & $1(10)$ & $4(44$ & $5(26)$ & $12(50)$ & $19(61)$ & $36(49)$ \\
\hline Number of mentio & & $1(33)$ & $5(62$ & $6(55)$ & $19(59)$ & $26(54)$ & $51(56)$ \\
\hline Number of *'s & c & $0 \quad(0)$ & $0 \quad(0$ & $0 \quad(0)$ & $2(67)$ & $1(17)$ & $3(23)$ \\
\hline
\end{tabular}

\section{WORK}

High School Teaching/Administration

$\begin{array}{llllllllll}\begin{array}{l}\text { Number of persons } \\ \quad \text { mentioning e }\end{array} & 0 & (0) & 0 & (0) & 0 & (0) & 4(17) & 11(35) & 15(19) \\ \text { Number of mentions } & 0 & (0) & 0 & (0) & 0 & (0) & 9^{c}(28) & 17(35) & 26(29) \\ \text { Number of *'s } & 0 & (0) & 0 & (0) & 0 & (0) & 1(33) & 4(67) & 5(38)\end{array}$

All Other Kinds of Work

$\begin{array}{lllllllll}\begin{array}{l}\text { Number of persons } \\ \quad \text { mentioning e }\end{array} & 2(20) & 2(22) & 4(21) & 2 & (8) & 2 & (6) & 8(11) \\ \text { Number of mentions } & 2(67) & 3(38) & 5(45) & 2 & (6) & 2 & (4) & 9(10) \\ \text { Number of *'s } & 1(100) & 3(100) & 4(100) & 0 & (0) & 1(17) & 5(38)\end{array}$


TABLE III (continued)

\begin{tabular}{|c|c|c|c|c|c|c|}
\hline Work Totals & $\begin{array}{l}\text { VA } \\
\text { N }(\%)\end{array}$ & $\begin{array}{l}\mathrm{A} \\
\mathrm{N}(\%)\end{array}$ & $\begin{array}{l}\mathrm{VA}+\mathrm{A} \\
\mathrm{N}(\%)\end{array}$ & $\begin{array}{l}\text { MA } \\
\text { N(\%) }\end{array}$ & $\mathrm{I}$ & $\begin{array}{l}\text { Total } \\
\mathrm{N}(\%)\end{array}$ \\
\hline $\begin{array}{c}\text { Number of persons } \\
\text { mentioning } \mathrm{e}\end{array}$ & $2(20)$ & $2(22)$ & $4(21)$ & $6(25)$ & $10(32)$ & $20(27)$ \\
\hline Number of mentions & $2(67)$ & $3(38)$ & $5(45)$ & $11(34)$ & $19(40)$ & $35(38)$ \\
\hline \multirow[t]{2}{*}{ Number of *'s } & $1(100)$ & $3(100)$ & $4(100)$ & $1(33)$ & $5(83)$ & $10(77)$ \\
\hline & \multicolumn{6}{|c|}{ Other (H.S. experience, grad.school, etc.) } \\
\hline $\begin{array}{l}\text { Number of persons } \\
\text { mentioning e }\end{array}$ & $(0)$ & $(0)$ & $(0)$ & $2(8)$ & $3(10)$ & $5(7)$ \\
\hline Number of mentions & $(0)$ & $(0)$ & $(0)$ & $2(6)$ & $3(6)$ & $5(4)$ \\
\hline Number of *'s & $(0)$ & $(0)$ & $(0)$ & $0(0)$ & $0(0)$ & $0(0)$ \\
\hline
\end{tabular}

Grand Totals

$\begin{array}{llllllllll}\begin{array}{l}\text { Number of persons } \\ \text { mentioning e }\end{array} & 3 & (30) & 4 & (44) & 7 & (37) & 13(54) & 23(74) & 43(58)^{\mathrm{d}} \\ \text { Number of mentions } & 3 & (3) & 8 & (9) & 11 & (6) & 32(14) & 48(17) & 91(13)^{\mathrm{e}} \\ \text { Number of *'s } & 1 & (4) & 3 & (9) & 4 & (8) & 3(2) & 6(8) & 13(7)^{\mathrm{f}}\end{array}$

a Is $\%$ of totals of Table, not category (B.A.).

b Is $\%$ of totals of Table, not category (B.A.).

c Persons had 2 masters or persons mentioned aspects of the category more than once; e.g., teaching in high school, then became principal.

d Number of different persons who mentioned anything covered by this Table.

$\mathrm{e}$ and $\mathrm{t}$ The percentages in each cell are the percentages of the total e's and *'s for all stages; e.g., total $(13 \%)$ is from $91 / 690 \times 100$. See Table I.

two different master's degrees.) Hence, the mention of a master's degree is one more (9) than the number of persons who mentioned getting the master's degree (8). Multiple mentions occur more frequently with other kinds of events later in this and other tables, particularly in those tables dealing with work. Also, the percentage figures for the second rows in each of the subtables is the fraction of the total number of events in each particular table. For example, under the VA's alongside "Number of mentions", after the " 1 " is a (33). The $33 \%$ means that that one is one out of 3 cases in this entire table that is mentioned by VA's. Looking at the last sub-table in each of the major tables, which is always the Grand Total, the second row tells the number of cases. What is different in the Grand Total table is that the numbers in parentheses which follow the total number of mentions (second row) is the percentage of all mentions for all tables, that is, of the 690 events. Actually, the $3 \%$ following the 3 in the VA column in the Grand Total subpart is $3 / 89 \times 100$. 
The treatment of the number of events that were signaled as most important is done in a similar way to that just described. The number is the number of events that were starred, but the numbers in parentheses are the percentages of the cases within that table, except in the instance of the Grand Total table where the numbers in parentheses are the percentage of all the starred events for all cases.

Looking at Table III's summary data on pre-Ph.D. activities first (Grand Totals), there is an appreciable increase in both the number of persons who mentioned pre-Ph.D. activities as well as the percentage of events mentioned as one reads from left to right. The sum of VA plus A is $37 \%$, rises to $54 \%$ for the MA's, and to $74 \%$ for the I's. Similarly, for the number of events mentioned, the figures rise from 6 to 14 to 17 . While there is a fair amount of mention of pre-Ph.D. activities, the numbers who star it are relatively the same independent of activity group. Also the number of stars is only about half of the percentage of total activity in this category, 7 vs. $13 \%$.

With respect to education, the VA's and the A's much less frequently mention the bachelor's degree (21\%) than do the MA's $(38 \%)$ and the I's $(55 \%)$. The M.A. degree is not mentioned as frequently as is the B.A. (This may be because getting the Ph.D. is very important; see Table IV. Since all earn the degree, getting the M.A. may not be nearly so noteworthy). No one gave earning the M.A. a star. Said another way, getting started in higher education at all is important (the B.A.), but from then until the culmination with a $\mathrm{Ph} . \mathrm{D}$., degrees are not critical. Furthermore, getting started in higher education seems to be much more important for the MA's and the I's than for the VA's and A's [2].

With respect to work engaged in prior to obtaining the Ph.D., an experience as a teacher or an administrator in a high school clearly separates the VA's and A's from the MA's and I's. A large number of work events were mentioned by the latter two groups. This difference will turn out to be a significant one, for it is these people who become college administrators and give much attention to that role. The VA's and the A's do not.

Regarding work activities that are not connected with high schools, the number of mentions is not very large but the number of people who do mention it found work then to be an important event in their lives. That is, there are an appreciable number of *'s, and most of the *'s that occur in pre-Ph.D. activities happen here. The non-high school work experiences were in fact more important for the VA's and A's than they were for the other two groups. (What can sometimes happen in calculating sub-totals is that differences between the groups disappear because they are cancelled by the difference in two sub-categories.)

The first thing to note in the Grand Total category in Table IV on graduate experiences and obtaining the Ph.D. is the very high percentage of persons (86) who mention something in this category, and that it is about 


\section{TABLE IV}

Ph.D. and Graduate School Experiences

\begin{tabular}{|c|c|c|c|c|c|c|}
\hline & \multicolumn{6}{|c|}{ EXPERIENCES AND EVENTS } \\
\hline & VA & $\mathrm{A}$ & $\mathrm{VA}+\mathrm{A}$ & MA & I & Total \\
\hline & $\mathrm{N}(\%)$ & $\mathrm{N}(\%)$ & $\mathrm{N}(\%)$ & $\mathrm{N}(\%)$ & $\mathrm{N}(\%)$ & $\mathrm{N}(\%)$ \\
\hline $\begin{array}{l}\text { Number of persons } \\
\text { mentioning } \mathrm{e}\end{array}$ & $2(20)$ & $3(33)$ & $5(26)$ & $7(29)$ & $5(16)$ & $17(23)$ \\
\hline $\begin{array}{l}\text { Number of mentions } \\
\text { of } \mathrm{e}\end{array}$ & $3(33)$ & $3(30)$ & $6(32)$ & $8(25)$ & $6(17)$ & $20(23)$ \\
\hline \multirow[t]{2}{*}{ Number of *'s } & $2(67)$ & $0 \quad(0)$ & $2(40)$ & 4(33) & $1(7)$ & $7(22)$ \\
\hline & \multicolumn{6}{|c|}{ General (Seminars, individuals, study, . . .) } \\
\hline $\begin{array}{l}\text { Number of persons } \\
\text { mentioning e }\end{array}$ & $1(10)$ & $0 \quad(0)$ & $1(5)$ & $3(12)$ & $7(23)$ & $11(15)$ \\
\hline $\begin{array}{l}\text { Number of mentions } \\
\text { of e }\end{array}$ & $1(11)$ & $0 \quad(0)$ & $1(5)$ & $6(19)$ & $7(19)$ & $14(16)$ \\
\hline \multirow[t]{2}{*}{ Number of *'s } & $0(0)$ & $0 \quad(0)$ & $0(0)$ & $1(8)$ & $2(13)$ & $3(19)$ \\
\hline & \multicolumn{6}{|c|}{ Totals (Experiences and Events) } \\
\hline $\begin{array}{l}\text { Number of persons } \\
\text { mentioning e }\end{array}$ & $3(30)$ & $3(33)$ & $6(32)$ & $10(42)$ & $12(39)$ & $28(38)$ \\
\hline $\begin{array}{l}\text { Number of mentions } \\
\text { of } \mathrm{e}\end{array}$ & $4(44)$ & $3(30)$ & $7(37)$ & $14(44)$ & $13(36)$ & $34(39)$ \\
\hline \multirow[t]{2}{*}{ Number of *'s } & $2(67)$ & $0 \quad(0)$ & $2(40)$ & $5(42)$ & $3(20)$ & $10(31)$ \\
\hline & \multicolumn{6}{|c|}{ Ph.D. EARNED/RECEIVED } \\
\hline $\begin{array}{l}\text { Number of persons } \\
\text { mentioning } \mathrm{e}\end{array}$ & $5(50)$ & $7(78)$ & $12(63)$ & $18(75)$ & $23(74)$ & $43(58)$ \\
\hline $\begin{array}{l}\text { Number of mentions } \\
\text { of } e\end{array}$ & $5(56)$ & $7(70)$ & $12(63)$ & $18(56)$ & $23(64)$ & $53(69)$ \\
\hline \multirow[t]{2}{*}{ Number of *'s } & $1(33)$ & $2(100)$ & $3(60)$ & $7(58)$ & $12(80)$ & $22(69)$ \\
\hline & \multicolumn{6}{|c|}{ Grand Totals } \\
\hline $\begin{array}{l}\text { Number of persons } \\
\text { mentioning } \mathrm{e}\end{array}$ & $8(80)$ & $7(78)$ & $15(79)$ & $21(88)$ & $28(90)$ & $64(86)$ \\
\hline $\begin{array}{l}\text { Number of mentions } \\
\text { of } \mathrm{e}\end{array}$ & $9(10)$ & $10(11)$ & $19(11)$ & $32(14)$ & $36(13)$ & $87(13)$ \\
\hline Number of *'s & $3(12)$ & $2(9)$ & $5(11)$ & $12(21)$ & $15(20)$ & $32(18)$ \\
\hline $\begin{array}{l}\text { Order of event, }{ }^{\mathrm{a}} \\
\text { Ph.D. Earned } \\
\text { (Range: } 0.11-1.00 \text { ) }\end{array}$ & 0.14 & 0.24 & 0.19 & 0.30 & 0.44 & \\
\hline
\end{tabular}

a Each e mentioned by a respondent was in a time sequence - from first to last. While number of e's ranged from 4 to 13 , each e could be expressed as a ratio - e.g., 2nd of 9,7 th of 11 , etc. By expressing each as a ratio (decimal), a mean for the group can be calculated. Since X of e's/group was 9 , a $1 / 9=0.11$ was the lowest possible, i.e., the first mentioned significant. For the VA's, getting a Ph.D. was \#1; for the I's, it was approaching the mid-point. 
the same proportion for each of the sub-groups. The differences between groups in the overall picture is not in the number mentioning nor in the number of events mentioned, but differences do appear with respect to the percentage of starred events. They go from 11 to 21 to 20 (sum of the VA's plus A's to the MA's to the I's). That is, while the event of getting this degree was important to all people, it was a much more significant one for those who are now inactive or only moderately active. Looking at fellowships and research grants and teaching assistantships, the number of events mentioned (second row in uppermost table) decreases appreciably from $32 \%$ to $25 \%$ to $17 \%$. Those who are VA or A apparently had more of this kind of support. (A reversal takes place in the second sub-part where other events in graduate school are mentioned which leads to a balanced effect when the sub-total is made.)

The extra numbers at the bottom of Table IV are also highly important. The footnote in the Table explains how they were calculated. What needs to be noted is that getting the Ph.D. was an event almost halfway through the career life of important things that happened to the I's $(0.44)$, but it was almost the first thing that happened to those who are the VA's $(0.14)$.

Eighty-five percent of the population mentions their first college or university appointment. This event is indeed a significant one for all the sub groups. Furthermore, the percentage of starred events here is somewhat greater than the number of events and shows the importance of the first college or university job.

Job changes within higher education show that MA's and I's are not moving towards the research universities, but the VA's and A's do (37\% vs. $17 \%$ vs. $7 \%$ ) [3]. Instead, they are moving to colleges or non-research universities. Other evidence in the self-reports that can be read between the lines (but which cannot be fully documented) indicates that the MA's and I's were moving to less research-focused institutions in order to receive promotions or to take on administrative appointments, such as heads of departments or deanships. Place of work matters for where one works is related to how actively one publishes. This is true rather early in the career and somehow establishes a habit of productivity that maintains itself up and on through retirement for those who are in the research university environment, but dampens or terminates the scholarly activity for those who move away from research universities. What is significant about the people who began in regional institutions or comprehensive-type colleges and universities is that they published as much as they did despite the less favorable scholarly environment in which they worked - unfavorable to the extent that the resources were undoubtedly less in the way of libraries and certainly with respect to the number of immediate colleagues engaged in scholarly activity. Said another way, the productive researcher is not the cosmopolitan man on 
the move. He is a stayer. When he finds a favorable environment, he settles in and sticks with his work.

Data dealing with job changes outside of higher education show that the percentage of stars is greater than the percentage of events, that is, when people did leave colleges or universities, it was an important step in their careers. The MA's are an atypical group in this category in terms of the percentage who mention it, the percentage of total events, and the very high percentage of starred events ( $35 \%$ in this category alone). The VA's and the A's have made no mention of work in business, government service, or the ministry. The only time they have been outside of their universities (that they mention), except for war service, is in a professionally related activity. Their moves outside higher educational institutions are not to a different kind of work; they are to a different place of work, and then for a short duration. Said another way, the VA's and the A's have been consistently engaged in their professional work from the time of their Ph.D., something which has not been true for the MA's or the I's.

In the summary totals of Table $V$ on scholarly writing, the VA's are a distinct group. They even separate themselves from the A's, particularly with respect to the percentage of the items that they award stars, 17\% appearing in this table as opposed to the $7 \%$ for the total population. There are also differences between the A's, the MA's and I's and the differences are appreciable. Turning to the upper part of the table, there is a rapid fall-off by each category on both first book published and second (and third) book published until it is only the VA's who mention this event. It is of some note, however, that by the time they get to the third book, they no longer give it a star. The subtotal for books shows the same appreciable separation by each of the sub-groups going from left to right. Actually the total on books is more dramatic than the Grand Totals for the next two categories - research publication and textbooks are not mentioned by either the VA's or A's. Hence the sums are somewhat leveled out.

It is not known whether any of those books that the VA's mentioned were textbooks, but they did not describe them as texts. There is a distortion in that neither the VA's nor A's mention a research publication. One assumes that they have published many articles, but articles do not receive the same attention that their books do. Maybe what is involved is that the MA's and I's are less inclined to do books and hence mention their research publications. From comments on the questionnaire form, it seems as if a distinguished book had a real impact on the career of the VA's and A's. It gave them a visibility that a research article does not. Their books brought attention to these people and shaped the rest of their career. It led to funding, an overseas appointment, future books. Writing became a habit for them in ways different from the others [4,5].

While the data on leaves overseas depict a small category in terms of 
TABLE V

Event Within CU's - Publications

\begin{tabular}{|c|c|c|c|c|c|c|}
\hline & $\begin{array}{l}\text { BOOKS } \\
\text { The Firs }\end{array}$ & st Book & & & & \\
\hline & VA & A & $\mathrm{VA}+\mathrm{A}$ & MA & & Total \\
\hline & $N(\%)$ & $\mathrm{N}(\%)$ & $\mathrm{N}(\%)$ & $\mathrm{N}(\%)$ & $\mathrm{N}(\%)$ & $\mathrm{N}(\%)$ \\
\hline $\begin{array}{c}\text { Number of persons } \\
\text { mentioning e }\end{array}$ & $8(80)$ & $6(67)$ & $14(74)$ & $6(25)$ & $4(10)$ & $24(32)$ \\
\hline Number of mentions & $8(42)$ & $6(75)$ & $14(52)$ & $6(46)$ & $4(27)$ & $24(60)$ \\
\hline Number of *'s & $2(50)$ & $1(100)$ & $3(60)$ & $1(33)$ & $0(0)$ & $4(33)$ \\
\hline & The Sec & ond Book & & & & \\
\hline $\begin{array}{l}\text { Number of persons } \\
\text { mentioning e }\end{array}$ & $4(40)$ & $2(22)$ & $6(32)$ & $2(8)$ & $1(2)$ & $9(12)$ \\
\hline Number of mentions & $5(26)$ & $2(25)$ & $7(26)$ & $2(15)$ & $1(7)$ & $10(25)$ \\
\hline Number of *'s & $2(50)$ & $0 \quad(0)$ & $2(40)$ & $0(0)$ & $1(25)$ & $3(25)$ \\
\hline & The Thi & Ird Book (o & more) & & & \\
\hline $\begin{array}{l}\text { Number of persons } \\
\text { mentioning } \mathrm{e}\end{array}$ & $4(40)$ & $0 \quad(0)$ & $4(21)$ & $0(0)$ & $0(0)$ & $4(5)$ \\
\hline Number of mentions & $6(32)$ & $0 \quad(0)$ & $6(22)$ & $0(0)$ & $0(0)$ & $6(15)$ \\
\hline Number of *'s & $0(0)$ & $0 \quad(0)$ & $0(0)$ & $0(0)$ & $0(0)$ & $0(0)$ \\
\hline & VA & A & $\mathrm{VA}+\mathrm{A}$ & MA & I & Total \\
\hline Book Publication Totals & $\mathrm{N}(\%)$ & $\mathrm{N}(\%)$ & $\mathrm{N}(\%)$ & $\mathrm{N}(\%)$ & $\mathrm{N}(\%)$ & $\mathrm{N}(\%)$ \\
\hline $\begin{array}{c}\text { Number of persons } \\
\text { mentioning e }\end{array}$ & $8(80)$ & $6(67)$ & $14(74)$ & $6(25)$ & $4(13)$ & $24(32)$ \\
\hline Number of mentions & $19(100)$ & $8(100)$ & $27(100)$ & $8(62)$ & $5(33)$ & $40(73)$ \\
\hline Number of *'s & $4(100)$ & $1(100)$ & $5(100)$ & $1(33)$ & $1(25)$ & $7(58)$ \\
\hline & RESEA & RCH PAPE & RS AND P & BLICAT & lONS & \\
\hline $\begin{array}{c}\text { Number of persons } \\
\text { mentioning e }\end{array}$ & $0 \quad(0)$ & $0 \quad(0)$ & $0 \quad(0)$ & $3(12)$ & $6(15)$ & $9(12)$ \\
\hline Number of mentions & $0 \quad(0)$ & $0 \quad(0)$ & $0 \quad(0)$ & $3(23)$ & $7(47)$ & $10(18)$ \\
\hline Number of *'s & $0 \quad(0)$ & $0 \quad(0)$ & $0 \quad(0)$ & $1(33)$ & $1(25)$ & $2(17)$ \\
\hline & VA & $\mathrm{A}$ & $\mathrm{VA}+\mathrm{A}$ & MA & I & Total \\
\hline Textbooks and Materials & $\mathrm{N}(\%)$ & $\mathrm{N}(\%)$ & $\mathrm{N}(\%)$ & $\mathrm{N}(\%)$ & $\mathrm{N}(\%)$ & $\mathrm{N}(\%)$ \\
\hline $\begin{array}{l}\text { Number of persons } \\
\text { mentioning e }\end{array}$ & $0 \quad(0)$ & $0 \quad(0)$ & $0 \quad(0)$ & $1(4)$ & $2(5)$ & $3(4)$ \\
\hline Number of mentions & $0 \quad(0)$ & $0 \quad(0)$ & $(0)$ & $2(15)$ & $3(20)$ & $5(9)$ \\
\hline Number of *'s & $0 \quad(0)$ & $0 \quad(0)$ & $(0)$ & $1(33)$ & $2(50)$ & $3(25)$ \\
\hline & Grand $\mathrm{T}$ & otals & & & & \\
\hline $\begin{array}{l}\text { Number of persons } \\
\text { mentioniıg e }\end{array}$ & $8(80)$ & $6(67)$ & $14(74)$ & $9(38)$ & $12(35)$ & $34(46)$ \\
\hline Number of mentions & $19(21)$ & 8 (9) & $27(15)$ & $13(6)$ & $15(5)$ & $55(8)$ \\
\hline Number of *'s & $4(17)$ & $1 \quad(5)$ & $5(11)$ & $3(5)$ & $4(5)$ & $12(7)$ \\
\hline
\end{tabular}


percentage of all the responses (only $2 \%$ ), it apparently is a very important event in the lives of the VA's. Fifty percent mention such an event, and that it is $9 \%$ of all of the mentions as opposed to $2 \%$ for the population as a whole. Also, $17 \%$ of these events received starred mentions by the VA group. The foundation grant, the visiting lectureship, the Fulbright, etc. separates the VA's and A's from the other two groups.

If one connects overseas experiences with the writing of books, the experience at this mid-point of their career was most likely a consequence of what they had done earlier, rather than as a precipitator of future events. On the other hand, for an overseas experience to have been such an important event, it must have led to a reinvigoration, a rededication, a source of new ideas. When VA's came back, they produced more books. A year abroad was an important event in their careers. As did the production of books, this career experience separates the VA's from the A's.

Table VI tallies career events that many mention (73\%) regarding the changes in their status or role that occurred while in their college or university. Status/role changes represent $18 \%$ of the starred events, while only $13 \%$ of all events. Furthermore, these changes again separate the VA's from all other groups, for they judge changing status or role much less important than the group as a whole. Only $40 \%$ mention it $-6 \%$ of all events, and $8 \%$ of the stars. Going back to the sub-parts of the table, the VA's have never mentioned promotion, whereas the others do. Also, VA's have not mentioned a service role or teaching (nor have the A's). In fact, the only role that the VA's do mention is the research one, and there the differences are appreciable - the VA's and A's being $32 \%$, to $17 \%$ for the MA's and to $5 \%$ for the I's.

Next, the differences completely reverse themselves when one examines the administrative activities. The VA's and A's simply have seldom mentioned administrative roles like directorships, chairpersonships, or deanships, whereas the role of chairperson is a highly mentioned event by the MA's and I's. In fact, the role of chairmanship receives $57 \%$ of the stars for the MA's. No VA or A person mentions having been a dean, whereas the other two groups do. The total administrative activities show a great shift from $16 \%$ to $54 \%$ to $55 \%$ in number of persons mentioning and from $21 \%$ to $39 \%$ to $52 \%$ for number of events mentioned.

Not only are the MA's and I's more likely to mention administrative activities but they are likely to mention them more than once. The administrative activity is one of the most distinct dividers of the career patterns of the two more active groups from the two less active publishers. It may be that the less successful research group led to administration, or conversely, a move into administration curtailed research. If one remembers that the MA's and I's had had administrative experience in high schools, it may be that they were destined for this role early in their careers. They had had satis- 


\section{TABLE VI}

Events Within CU's - Changes in Status or Role

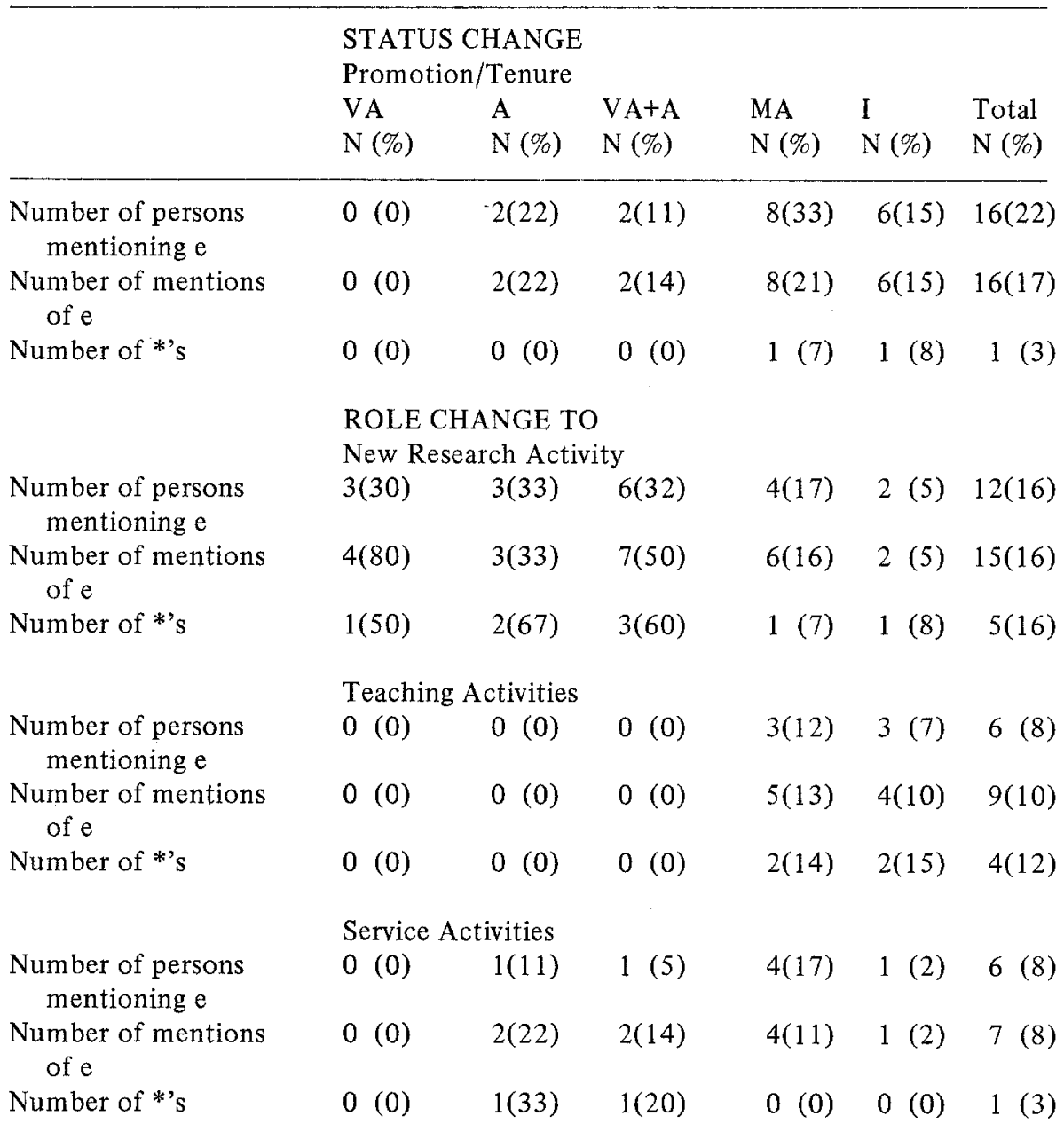

ADMINISTRATIVE ROLES

Director (Institute, ...)

$\begin{array}{llllll}\text { VA } & \text { A } & \text { VA+A } & \text { MA } & \text { I } & \text { Total }\end{array}$

$\mathrm{N}(\%) \quad \mathrm{N}(\%) \quad \mathrm{N}(\%) \quad \mathrm{N}(\%) \quad \mathrm{N}(\%) \quad \mathrm{N}(\%)$

Number of persons

$\begin{array}{llllll}0(0) & 1(11) & 1(5) & 1(4) & 0(0) & 2(3)\end{array}$

mentioning $\mathrm{e}$

Number of mentions

$0(0) \quad 1(11) \quad 1(7)$

$1(3) \quad 0(0) \quad 2(2)$

of $\mathrm{e}$

$0(0) \quad 0(0) \quad 0(0)$

$0(0) \quad 0(0) \quad 0(0)$

Number of *'s 
TABLE VI (continued)

\begin{tabular}{|c|c|c|c|c|c|c|}
\hline & \multicolumn{3}{|c|}{ Department Chair/Head } & & & \\
\hline $\begin{array}{l}\text { Number of persons } \\
\text { 'mentioning e }\end{array}$ & $1(10)$ & $1(11)$ & $2(11)$ & $9(38)$ & $11(27)$ & $22(30)$ \\
\hline $\begin{array}{l}\text { Number of mentions } \\
\text { of } \mathrm{e}\end{array}$ & $1(20)$ & $1(11)$ & $2(14)$ & $11(29)$ & $13(32)$ & $26(28)$ \\
\hline Number of *'s & $1(50)$ & $0(0)$ & $1(20)$ & $8(57)$ & $4(31)$ & $13(41)$ \\
\hline $\begin{array}{l}\text { Number of persons } \\
\text { mentioning } \mathrm{e}\end{array}$ & $\begin{array}{l}\text { Dean } \\
0(0)\end{array}$ & $0(0)$ & $0(0)$ & $3(12)$ & $9(24)$ & $12(16)$ \\
\hline $\begin{array}{l}\text { Number of mentions } \\
\text { of } \mathrm{e}\end{array}$ & $0(0)$ & $0(0)$ & $0(0)$ & $3(18)$ & $12(30)$ & $15(16)$ \\
\hline Number of *'s & $0(0)$ & $0(0)$ & $0(0)$ & $2(14)$ & $3(23)$ & $5(16)$ \\
\hline
\end{tabular}

ROLE CHANGE TO ADMINISTRATION

(Totals)

$\begin{array}{llllll}\text { VA } & \text { A } & \text { VA+A } & \text { MA } & \text { I } & \text { Total }\end{array}$

$\mathrm{N}(\%) \quad \mathrm{N}(\%) \quad \mathrm{N}(\%) \quad \mathrm{N}(\%) \quad \mathrm{N}(\%) \quad \mathrm{N}(\%)$

\begin{tabular}{lcccccc}
\hline $\begin{array}{l}\text { Number of persons } \\
\text { mentioning e }\end{array}$ & $1(10)$ & $2(22)$ & $3(16)$ & $13(54)$ & $17(55)$ & $33(45)$ \\
$\begin{array}{l}\text { Number of mentions } \\
\text { of e }\end{array}$ & $1(20)$ & $2(22)$ & $3(21)$ & $15(39)$ & $25(62)$ & $43(47)$ \\
$\begin{array}{l}\text { Number of *s } \\
\text { number }\end{array}$ & $1(50)$ & $0(0)$ & $1(20)$ & $10(71)$ & $7(54)$ & $18(56)$
\end{tabular}

OTHER (Counseling, . . .)

\begin{tabular}{lllllll} 
& VA & A & VAtA & MA & I & Total \\
& N $\%)$ & N (\%) & N (\%) & N (\%) & N (\%) & N (\%) \\
\hline $\begin{array}{l}\text { Number of persons } \\
\text { mentioning e }\end{array}$ & $0(0)$ & $0(0)$ & $0(0)$ & $0(0)$ & $2(6)$ & $2(3)$ \\
$\begin{array}{l}\text { Number of mentions } \\
\text { of e }\end{array}$ & $0(0)$ & $0(0)$ & $0(0)$ & $0(0)$ & $2(5)$ & $2(2)$ \\
$\begin{array}{l}\text { Number of *'s } \\
\begin{array}{l}\text { Number of persons } \\
\text { mentioning e }\end{array}\end{array}$ & $0(0)$ & $0(0)$ & $0(0)$ & $0(0)$ & $2(15)$ & $2(6)$ \\
$\begin{array}{l}\text { Number of mentions } \\
\text { of e }\end{array}$ & $5(40)$ & $5(56)$ & $9(47)$ & $21(88)$ & $24(77)$ & $54(73)$ \\
Number of *'s & $2(8)$ & $3(14)$ & $5(11)$ & $14(24)$ & $13(17)$ & $32(18)$
\end{tabular}

factory administrative experiences, enjoyed them, and no doubt did them well [6].

With respect to honors received, there is a distinct falling off from the $74 \%$ of the VA's and A's mentioning such an event to the $38 \%$ of MA's and 
$26 \%$ of the I's. Moreover, the A's mention national honors received even more frequently than do the VA's. It is worth noting that the VA's do not give a single star to any of these honors that they received, whereas $32 \%$ of all of the stars that the A's mentioned occur in this category. The VA's saw their books as being more significant than they did the honors that might have come to them as a consequence of the books. In fact, that they did not mention promotions and role changes makes the VA's a distinct sub-group from the A's. One could also suppose that the VA's and the A's also had roles in state and local societies, at least at one time in their careers, but they simply did not put these in the group of 10 or so things they thought most important. The MA's and the I's, however, did give state and local honors some mention.

As for the official act of retirement, it is not a frequently starred event, only $3 \%$ of the cases of the total population in contrast to $9 \%$ mentioning it. It is somewhat more of a starred event for the I's than for any other group ( $7 \%$ vs. $3 \%$ for the population as a whole), but the numbers here are small [7]. What is of interest is that the mention of retirement is much more prevalent among the I's (56\%) and the MA's (46\%) than it is for the VA's and A's (32\%). The VA's talk about emeritus status, an appointment at another university, and continued employment within universities, with a fall-off towards the MA's and I's. One assumes others received emeritus status, but did not mention it, although conferring that title may not have been quite as automatic when these people were retiring as it currently seems to be.

Overall, the VA's apparently do not take retirement as a particularly salient event, but keep right on with their work, their scholarly interests, and active production. For the I's and the MA's, retirement is much more of a sharp division between what they had been doing and what they are now doing. This would be especially true for those who were in administrative or purely teaching roles when they did retire. Retirement for them indeed is a clear stopping of what one has been doing [8].

\section{Summary}

Figure 1 is a schematic summary of the career events of the social scientists. The rectangle at the top shows their undifferentiated origins, essentially middle class and from farms. Each succeeding rectangle depicts a career event affecting a significant percentage of the subjects, beginning with the A.B. degree and progressing essentially chronologically downward through retirement and to current work. In the parentheses on the left of each career stage is the percentage of the VA's plus A's who mentioned the event; the figure in the parentheses on the right is the percentage of the MA's 


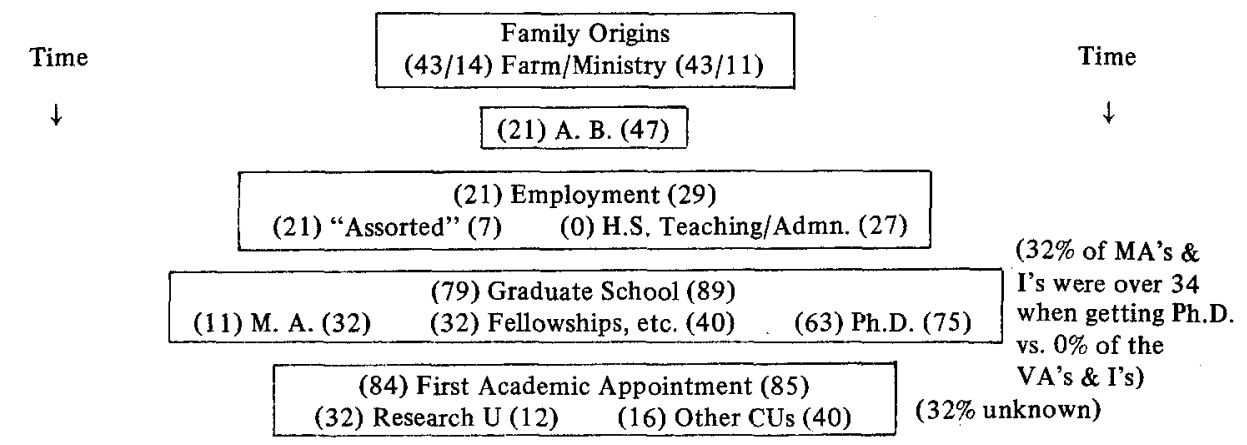

(74) Work Within CUs (38)

(32) Research (11) (74) Books Written (13) (0) Articles (16) (15) Teaching/Service (20)

\begin{tabular}{|ccccc|}
\hline $\begin{array}{c}\text { Job Changes Outside CUs } \\
\text { Military } \\
\text { (21) Service (20) }\end{array}$ & (0) Business (13) & (0) Ministry (9) & (0) Govt. (5) & (26) Related (31) \\
\hline
\end{tabular}

(84) Changes Within CUs (82)

(37) To Research U (13) (0) To Other CUs (22)

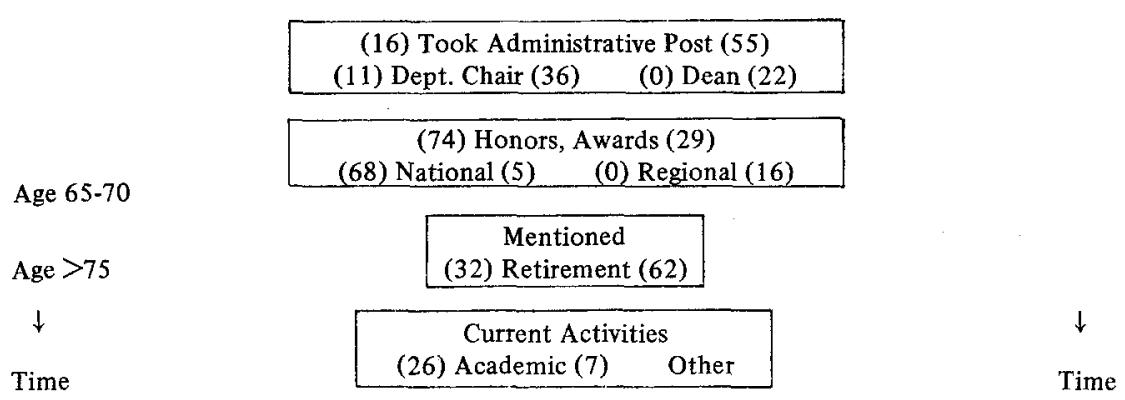

Fig. 1. Selected Career Events - VA's and A's* vs. M's and I's

* Figure in parentheses on the left is \% of VA's and A's mentioning event; figure in parentheses on the right is \% of MA's and I's mentioning event.

plus I's who mentioned each event. (For example $21 \%$ of the VA's plus A's mention earning the A.B. compared with $47 \%$ of the MA's and I's.) The two groups were much the same in terms of socioeconomic origins (middle class and farming stock), childhood relationships and personality characteristics but their career paths diverged markedly after obtaining the A.B. Most of the very active and active publishers obtained their Ph.D. at a younger age, began work in a research university (or moved to one quite early in their career), produced one or more books which brought them notice, and generally stayed in a research environment throughout their lives, including the years after formal/institutional retirement. While not cosmopolitans in Gouldner's $(1957 ; 1958)$ sense of consultants and persons on the 
move, they do have Merton's (1957) outer reference group in that they have made impacts on their discipline, received national recognition for their scholarly contributions, and are personally rewarded by peer recognition across the country and abroad.

On the other hand, those social scientists who published fewer articles during their sixties tended to enter the work force - frequently in high school teaching and administration - before completing graduate school (at a later age), began their academic career in a regional university or moved to one later on, tended to try non-academic jobs, moved into administrative roles as department heads and deans, and disengaged themselves from their career work at the time of retirement. Some had national impacts on their disciplines - as an editor of a prestigious journal, for example - but most were locals in the Mertonian sense of immediate reference group (but not in terms of career mobility). The MA's and I's had a more diverse career in terms of focus, activity, and place of work and one in which nearly half of their significant career events occurred before beginning work in a university. For the VA's and A's, their careers began with earning the Ph.D. and remained distinctively singular in focus.

In addition to the summaries just presented, a number of conclusions seem warranted:

(1) Rate of (article) productivity is a fruitful variable for analyzing behavior. Had this analysis been conducted along lines of family background, say, or on the basis of personality characteristics, no career patterns would have emerged. This dependent variable has retained its power through today, an indication that one has identified a fundamental attribute of an occupational group (see, e.g., Blackburn et al., 1978).

(2) Work environment - place of work - is a principal predictor of scholarly output, then as well as now. Whether the individual is choosing the institution or the university is selecting the individual is not as clear as one would like. It seems this population had a greater degree of choice than exists in the more recent past and today. For these 74 social scientists it appears as if the status of the graduate school was less critical than is currently the case. Recent data show that entry into the productive work environment is highly dependent upon place of graduation (Crane, 1965), even for an underrepresented group like women (Cameron, 1978).

(3) An early start - Ph.D. at a young age - is also a principal predictor of scholarly output, also then as well as now (Raymond, 1967; Cole and Cole, 1973). Publishing becomes habitualized and becomes a regular ingredient of the work life. It persists and carries right through retirement for high producers rather than waning in the later years. Current data are in accord with this finding of Allison and Stewart (1974). 
(4) From the above, especially (2) and (3), it can be argued that sociological variables account better for career patterns than do psychological ones. The organizational structure and functioning have shaped the job trajectory, not vice versa.

(5) Academics do have distinct and definable career stages they pass through - i.e., the notion of a career stage is a fruitful concept; but (a) not all U.S. male social scientists pass through all of the stages; and (b) the stages are not neatly clustered.

(6) With respect to adult development theory, some phenomena seem to corroborate Hall and Nougain's (1976) pre-work stage, especially for the MA's and I's. On the other hand, other phenomena have no counterparts. For example, their retirement stage and Super's decline stage do not describe the VA's and A's. Also, when events were plotted by either chronological or career age, points did not cluster as adult development theory would predict but rather were randomly scattered over the time lines. (Of course, the data gathering technique employed here may be inappropriate for a fair test of developmental theory.)

\section{Discussion}

First of all, some caution must be exercised in interpreting the findings. For example, subjects reported only a handful of events from a long, rich, and rewarding life. We know only a minute fraction of their distinguished careers. There is an unconscious tendency to discount what was not mentioned although it is known that other important events took place.

Also, this cohort has lived through a unique period of history, one that will not be duplicated by another generation. By way of illustration, both the fact of their ages with respect to World War I and II and their arrival at mandatory retirement when there was an extensive faculty shortage, certainly affected possible career interruptions and the ease of continued scholarly activity beyond age 65 . In addition, these were all social scientists. The humanist's and natural scientist's creative product is quite different in its nature, the form it takes, the kind of colleagueship involved, and in the time required for production. What career patterns are for other academics needs to be investigated and cannot be inferred from our findings [9]. Furthermore, our sample is exclusively masculine. One anticipates different patterns for women faculty [10].

Second, while there is insufficient data here from which to build a new career development model, the methodology created for analyzing this data would seem to be fruitful for other inquiries. There are, of course, some 
clues in our findings - the importance of early work and school experience, for example. Also, the importance of the work environment suggests that exchange theory (Dowd, 1975), viz., having the opportunity to give to others so as to be able to receive, may be more fruitful to pursue than is the more frequently used disengagement theory (Cummings and Henry, 1961; Roman and Taietz, 1967; Atchley, 1971). However, such hoped-for theoretical advancements reside in the happy residual of "future research."

\section{Notes}

1 The categories included all but $2 \%$ of the e's mentioned and the miscellaneous category had none of the most significant e's. Hence, the classificatory scheme included almost all of the cases and every case goes into one category and only one, the first criterion for an acceptable system of classification.

2 Other data show a remarkably homogeneous childhood for all subjects in terms of SES, recreational activities, relations with others, hobbies, etc.

3 Presumably many VA's and A's began their careers at research universities and hence fewer of them would be in a position to move to one. Hence, the $37 \%$ is even more significant.

4 It must be remembered that these are social scientists not natural scientists, where research articles lead to fame.

5 One is also surprised by things that might have been mentioned but were not. For example, not a single one of the subjects talked about a distinguished contribution a particular discovery, a theory that might be associated with him. This absence again may be because of the discipline - the social sciences, rather than the natural sciences. One possible explanation is that the I's did do some research but it did not lead to the production of a visible book from which they might have launched a scholarly career.

6 Also, if the head of a department of a research university is really a chair rather than a head, that is, moves in and out on a rotating basis, the VA's might have served a term as a chairman but did not see that role as a significant part of their careers. On the other hand, colleges and regional universities are (were) more likely to make these administrative posts permanent positions, i.e., headships, and hence this event would be seen to be much more significant. One also assumes the role was taken on because the person desired it. In this sense, it was an activity they sought and achieved.

7 There have been a fair number of inquiries about U.S. faculty satisfaction with retirement (see, e.g., Rowe, 1976) but none which follow the individual's entire career. In the main, the studies show generally high satisfaction, more so for those who engage in scholarly activity and less so for those who were dependent upon teaching and more likely are unable to continue in that role.

8 Whether there are consequences from the sharp separation from pre-retirement to after retirement in other dimensions of their lives is not possible to ascertain from these data. It would be interesting to follow up on.

9 Despite the last two mentioned cautions, in a study now in progress, Baldwin (1978) is finding very similar critical career events for U.S. college professors which are for the most part independent of academic discipline. 
10 Cameron (1978) has data on successful U.S. women researchers that show that $60 \%$ of them are married to professors. Dual careers are in progress. (Only one wife in our sample was a professional. The others were described as "helpers", "supporters", or "companions". They typed manuscripts and entertained graduate students.) Cameron's women also have a strong mentor relationship, a linkage none of our male social scientists ever mentioned. Cameron's males do not either.

\section{References}

Allison, Paul, D. and Stewart, John A. (1974). "Productivity differences among scientists: Evidence for accumulative advantage," American Sociological Review 39(4): 596-606. Atchley, Robert C. (1971). "Disengagement among professors," Journal of Gerontology 26(4): 476-480.

Baldwin, R. G. (1978). "The Faculty Career Process: Continuity and Change," Ph.D. dissertation, University of Michigan, in progress.

Blackburn, Robert T., Behymer, Charles E. and Hall, David E. (1978). "Research note: Correlates of faculty publications," Sociology of Education 51:132-141.

Cameron, Susan M. (1978). "Women faculty in academia: Sponsorship, informal social networks, and career success," unpublished Ph.D. dissertation, University of Michigan.

Cole, Jonathan, R. and Cole, Stephen. (1973). Social Stratification in Science. Chicago: University of Chicago Press.

Crane, Diana. (1965). "Scientists as major and minor universities: A study of productivity and recognition," American Sociological Review 30: 699-714.

Cummings, E. and Henry, W. E. (1961). Growing old: The process of disengagement. New York: Basic Books.

Dowd, J. (1975). "Aging as exchange: A preface to theory," Joumal of Gerontology 30: $584-596$.

Gouldner, A. W. (1957). "Cosmopolitans and locals: Toward an analysis of latent social roles - I," Administrative Science Quarterly 2: 281-306.

Gouldner, A. W. (1958). "Cosmopolitans and locals: Toward an analysis of latent social roles - II," Administrative Science Quarterly 2: 444-480.

Hall, D. T. and Nougaim, K. (1968). "An examination of Maslow's need hierarchy in an organizational setting." Organizational Behavior in Human Performances (3): 12-35.

Havighurst, R. J., McDonald, W. J., Maeulen, L. and Mazel, J. (1979). "Male social scientists: Lives after 60," The Gerontologist 19(1): 55-60.

Merton, Robert K. (1957). "Patterns of Influence: Local and Cosmopolitan Influentials," in Robert K. Merton, ed., Social Theory and Social Structure, pp. 368-380. Glencoe, IL.: Free Press.

Raymond, J. C. (1967). "Publications, Production of Knowledge, and Career Patterns of American Economists," unpublished Ph.D. dissertation. University of Virginia.

Roman, P. and Taietz, P. (1967). "Organizational structure and disengagement: The emeritus professor," Gerontologist 7(3): 147-152.

Rowe, A. R. (1976). "Retired academics and research activity," Journal of Gerontology 30(4): 456-461.

Spilerman, Seymour (1977). "Careers, labor market structure, and socioeconomic achievement," American Journal of Sociology 83(3): 551-593. 